Jurnal Bisnis dan Manajemen, Volume 20, No. 1, March 2019, p. 15-31

\title{
BUSINESS MODEL FORMULATION FOR E-NEWSPAPER IN INDONESIA (CASE STUDY: PIKIRAN RAKYAT)
}

\author{
Aditia Sovia Pramudita ${ }^{1}$, Amri Yanuar ${ }^{2}$, Tamadara Hilman ${ }^{3}$ \\ 1,2,3 Politeknik Pos Indonesia, Indonesia
}

\begin{abstract}
The newspaper industry is undoubtedly entering a declining period. Changes in customer behavior become a major problem for newspaper companies. Demand for electronic media is increasing every year. The electronic newspaper is the only way for newspaper companies to survive in this industry. This study aims to formulate an economically sustained business model through value chain analysis and business model canvas. The research methods used in this study are interviews and consolidation studies. Two main concepts are being used in this research, namely, value chain analysis and business model canvas. Benchmarking with sustained online media company is also needed. The results of this study are business model from the related company that has been economically sustained based on profitability ratio that can be adopted for Pikiran Rakyat e-newspaper. Based on the framework, business model recommendations must be able to define consumers into two, namely audience and advertiser, and determine how to monetize it as a revenue stream. There are two stages in the development of recommended business model from this study; the first stage Pikiran Rakyat needs to focus on community models to gain audiences and then switch into advertising models gradually to monetize their audience. At last, e-newspaper is recommended as an online media commerce model to widen the possibility of revenue stream`s choices.
\end{abstract}

Keywords: E-newspaper, business model canvas, online media, value chain analysis

\section{FORMULASI MODEL BISNIS SURAT KABAR ELEKTRONIK DI INDONESIA (STUDI KASUS: PIKIRAN RAKYAT)}

\begin{abstract}
ABSTRAK
Industri surat kabar sudah tidak diragukan lagi telah memasuki masa declining. Perubahan prilaku pelanggan menjadi masalah utama bagi perusahaan surat kabar. Permintaan terhadap media elektronik semakin meningkat setiap tahunnya. Surat kabar elektronik merupakan jalan keluar untuk bisa terus bertahan di industri ini. Tujuan dari penelitian ini adalah untuk bisa merumuskan bisnis model yang memiliki keberlangsungan ekonomi melalui analisis rantai nilai dan business model canvas. Metode riset yang digunakan dalam penelitian ini adalah wawancara dan studi konsolidasi. Ada dua konsep utama yang digunakan dalam penelitian ini yaitu analisis rantai nilai dan model bisnis kanvas. Pembandingan dengan perusahaan media online yang sudah sustain juga diperlukan. Hasil dari penelitian ini adalah model bisnis dari perusahaan pembanding yang sudah berkelanjutan secara ekonomis berdasarkan rasio profitabilitas yang dapat diadopsi untuk surat kabar elektronik Pikiran Rakyat. Secaral Berdasarkan kerangka kerja, rekomendasi model bisnis harus dapat mendefinisikan konsumen menjadi dua, yaitu audience dan advertiser, dan menetapkan cara untuk bisa memonetisasinya sebagai revenue stream. Terdapat dua tahapan dalam pengembangan bisnis model yang menjadi rekomendasi dari penelitian ini yaitu pada tahapan pertama Pikiran Rakyat perlu fokus pada community model dengan tujuan untuk mendapatkan audience mereka terlebih dahulu yang kemudian berubah menjadi advertising model secara bertahap dalam rangka untuk memonetisasi audience mereka. Pada akhirnya, surat kabar elektronik disarankan untuk menjadi online media commerce model sehingga mereka memiliki variasi revenue stream yang lebih luas.
\end{abstract}

Kata-kata Kunci: Surat Kabar Elektronik, Media Online, Business Model Canvas, Analisis Rantai Nilai

Korespondensi: Aditia Sovia Pramudita, ST., MBA. Politeknik Pos Indonesia. Jln. Sariasih No.54, Sarijadi, Sukasari, Kota Bandung, Jawa Barat 40151. Email: aditiasovia@poltekpos.ac.id

Submitted: January 2019, Accepted: March 2019, Published: March 2019

ISSN: 1412 - 3681 (printed), ISSN: 2442 - 4617 (online), Website: http://journal.feb.unpad.ac.id/index.php/jbm 
Jurnal Bisnis dan Manajemen, Volume 20, No. 1, March 2019, p. 15-31

\section{INTRODUCTION}

Internet and communication technology (ICT) has already affect products and services distribution. This condition also has an impact in the newspaper industry in term of revolutionizing the journalistic world (Sun \& Guo, 2004). In the use of ICT, time delivery and distribution cost will be reduced; and a broader chance to communicate with the audience itself (Flavian, Gurrea, \& Orús, 2009). This ICT development condition creates a new industry which is called electronic newspaper (enewspaper).

Newspaper industry condition in Indonesia is declining. Based on Serikat Perusahaan Pers, newspaper readership was $25.1 \%$ in 2006 , and it is declining in 2010 into 15\% (Republika, 2011). This result has also been strengthened by Nielsen Media which the newspaper readership is also declining in the following years until 2014.

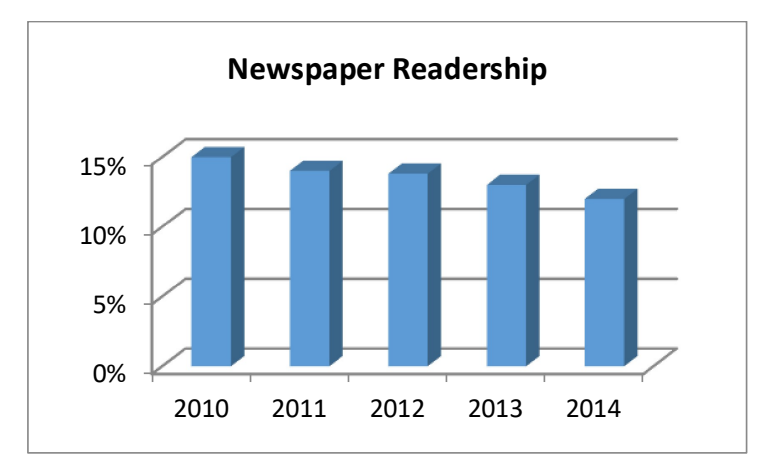

Figure 1. Newspaper Readership in 10 Cities in Indonesia

Source: (Nielsen, 2015)

Based on figure 1, in the past five years, newspaper readership is declining from time to time. Based on the fact, it can be concluded that the newspaper industry is facing a decline phase in the product life cycle. The decline phase is the phase in PLC where the phase can return to another phase in plc depending on the success of the organization. Decline phase is a replaceable phase of the PLC that can continue back to the other stages which depend on the success of the organization by chosen strategy, demands, ongoing support, and services or user needs. Most organizations choose one of the following options for continuing, which is going back to maturity or reinvesting for more producing or developments, harvesting, which means maximizing financial (Soltani, 2012).

There is no problem with their interest in reading. Nielsen shows that penetration in printed media is around $8 \%$. Furthermore, the problem is they only switching their media from print into digital media. In 2017, digital media readership had a penetration rate of around $11 \%$. Interestingly, digital media also can grab the future newspaper's consumer, which is generation $\mathrm{Z}$ readership (10-17 years old) (Lubis, 2017). That article shows that there is no problem with the newspaper's reader; the problem lies on the platform itself.

In order to survive in this industry, newspapers company should transform themselves and accept ICT as its core business, which means that newspaper companies should shift their business into e-newspaper companies. Unfortunately, the role of e-newspaper in Indonesia mostly becomes another distribution channel for them. When newspaper companies use e-newspaper as their distribution channel, it shows that they are not sure with the business model they should use (Ottosen \& Krumsvik, 2012). Most of 
Jurnal Bisnis dan Manajemen, Volume 20, No. 1, March 2019, p. 15-31

the newspaper companies provide free enewspaper and place e-newspaper as a complement product.

Young generation tends to choose the digital newspaper to compare with print. Since the young generation will become a potential customer for newspaper companies in the future, companies need to focus on how to reach them. Newspaper companies need to adapt to the changing behavior and start to develop a platform that can reach them eventually in order to grab the market share. E-newspaper is a solution that they need to focus on, but in the meantime, newspaper companies should formulate their business model first if they want to shift into e-newspaper.

As stated before, since e-newspaper is a new form of the newspaper business, revenue stream and choices of value become a critical part in the business model. This research is using Pikiran Rakyat (PR) as research object since PR is a newspaper company with the highest number of readers (readership) in West Java and number 7th as the most popular newspaper in Indonesia (Sheftiawan, 2017).

Pikiran Rakyat (PR), as the research object, also already developed e-newspaper as mitigation action to overcome the potential future consumer. E-newspaper is projected into the future of PR since PR's sales also are declining like any other newspaper companies, even though PR`s enewspaper still could not produce any revenue. Based on those facts, it seems impossible for enewspaper to be economically sustained.
In order to overcome those problems, Business Model Canvas (BMC) is suitable to be used since BMC is capable of defining each critical aspect such as functional factors, financial factor, and value proposition. Furthermore, BMC also can allow the business practitioner to analyze, manage, understand, share, prospect, and patent a business better (Osterwalder, Pigneur, \& Tucci, 2005). With those capabilities, BMC can give comprehensive solution toward the problem, which can be easily understood for both practitioner and academician. Based on those explanations, the research question of this research is which business model is suitable for Indonesia e-newspaper, which can provide economic sustainability, especially for PR as the object of study.

\section{LITERATURE REVIEW}

\section{E-Newspaper}

The Internet has a competitive displacement effect on traditional media in the daily news domain with the largest displacements occurring for television and newspapers (Panda \& Swain, 2011). The newspaper industry is struggling with harsh economic realities and is seeking new revenue sources. Many newspapers have added online video content in an attempt to compensate for the lost revenues from the decline in traditional print media sales, but the adaptation of these new formats has not been smooth, and many are still struggling to capture the full value (Hallgren \& Nylund, 2018).

A newspaper plays an essential role in disseminating current information and events and 
Jurnal Bisnis dan Manajemen, Volume 20, No. 1, March 2019, p. 15-31

keeps its readers up-to-date. The electronic newspaper or e-newspaper is a self-contained, reusable, and refreshable version of a traditional newspaper that acquires and holds information electronically. Moreover, electronic newspapers retrieve information electronically from online databases, process it electronically with word processors, desktop publishing packages and a variety of more technical hardware and software, and transmit it electronically to the end-users (Panda \& Swain, 2011). The development of electronic news production is predicted to be a replacement for the printed newspaper, but only when something better than a PC screen comes into widespread use (Panda \& Swain, 2011). Enewspaper is a traditional newspaper distributed by ICT through any media.

\section{Value Chain Analysis}

Porter's idea regarding the value chain is to describe all of the company's activities in order to generate revenue through the different production process, distribution, and after-sales services. Since there is a product's movement in the process, each product's movement is assumed to add value to the product (Meijer, 2006). Furthermore, the value chain can sort out business into major activities, which can lead to the mapping of competitive advantage's sources (Abecassis-Moedas, 2006).

There are two ways to classify value chain based on the driven factors which are buyer-driven or product-driven. The buyer-driven chain is a value chain which has characteristics that as labor intensive, consumer goods in a large retailer, and merchandisers play an essential role. While product driven chain is a value chain which has characteristics as a capital intensive and technology-oriented industry. In product driven chain, production network plays an important role to make value chain works properly (AbecassisMoedas, 2006). Regardless of what is the driven factor, value added is always reflected through each operational process, which implies value creation and or value capture (Chivaka, 2005).

The business strategy that is implemented in a company requires investment in both financial or non-financial resources. This investment is needed to lead to value-added, which implies both value creation and value capture (Chivaka, 2007). A series of research examining value chain consists, which is showing the chain's player capability to compete and succeed depends on their position in the industry chain (Danskin, Englis, \& Solomon, 2005). Research is focusing on each stage of the chain, which showed from the raw material into distributing product to the final consumer. The key finding of the study showed that external knowledge has an essential factor in bringing a member of a chain closer and generating value added in each stage.

It is clear that value-creating activities lie at two levels, which is within the industry and within the company itself (Chivaka, 2005). The ability to deliver high-performance product or service to the customer is a purpose of value creation (Networks \& Wilson, 2001). Value chain analysis requires "market mapping" in order to track and analyze the contribution of the chain`s 
Jurnal Bisnis dan Manajemen, Volume 20, No. 1, March 2019, p. 15-31

actors. Interaction between value chains can be measured and analyzed to obtain the performance of the chain. Furthermore, market mapping functions are to define the enabling environment and service providers. Enabling environment is an external factor that is relevant to the industry, such as infrastructure, policies, and regulations that shaped market condition. Service providers are an internal condition within the company, which can be controlled, such as supplier market information, financial services, transport services, $R \& D$, and level of accreditation (Meijer, 2006).

\section{Business Model Canvas}

A business reference model is a reference model, concentrating on the architectural aspects of the core business of an enterprise, service organization, or government agency (Kaltum, Zusnita, \& Bernik, 2018). The business model is a concept that has grown and has tried to define from time to time. Osterwalder, Pigneur and Tucci in 2005, affirms that the concept of a business model that appeared for the first time in an academic article in 1957 and then in the title and abstract papers in 1960 but only became popular in the 1990s. The attention focused on the concept that met between 1995 and 2010 (Zott, Amit, \& Massa, 2011). Osterwalder defends the view that where, through a review of a significant number of publications studying the evolution of the term business model, which enables it to conclude that the terms used are often linked to the internet but not exclusively refer to it (Osterwalder et al., 2005).
To clarify the process of evolution of the business model, by displaying definitions and classifications more sequential and integrated different authors expressed about the concept of the business model. With the proposed evolutionary phase, stated that the research business model has matured over the years. Although researchers have not leaned on each other's work and findings extensively, certain progress can be observed (Hendrix, Hidayat, \& Hidayat, 2018).

The framework is formulated, which consists of parameters of the value network, functional architecture, financial modeling, and value proposition. This framework is directed at the internal mechanisms of a business but does not take into account customers, environment, and competitors. Therefore did not cover all aspects of a business model (Ballon, 2007). Four essential parameters of a business model: notion of value (e.g., value stream, customer value, value proposition), financial aspects (e.g., revenue streams, cost structures) and aspects related to the architecture of the network between the firm and its exchange partners (e.g., delivery channels, network relationships, logistical streams, infrastructure) (Zott et al., 2011).

The analyzability and communicability are improved by proposing a business model framework in the mold of a canvas (Osterwalder et al., 2005). The canvas allows the business practitioner to analyze, manage, understand, share, prospect, and patent a business better (Osterwalder et al., 2005). The framework which is used in this 
Jurnal Bisnis dan Manajemen, Volume 20, No. 1, March 2019, p. 15-31

research, consist of four dimensions of a business

model: value, the architecture of the relation between firm and exchange partner, what the firm is doing and financial aspects.

Table 1. Business Model Canvas Elements

\begin{tabular}{ll}
\hline & Building Block of Business Model Canvas \\
\hline Value & Value Proposition \\
The architecture of the relation between firm & Key Partners, Customer Relationship, Customer \\
and exchange partner & Segment, Channels \\
What the firm is doing & Key Activities, Key Resources \\
Financial Aspects & Cost Structure, Revenue Stream \\
\hline
\end{tabular}

Source: (Coes, 2014)

\section{Value Chain Analysis and Business Model Canvas}

The use of value chain analysis is to determine the company`s competitive advantage since value chain analysis can identify strength and weakness from internal condition (Ensign, 2001).

Competitive advantage itself is carried out by value creation (Ankli, 2014). Based on those facts, value chain analysis' purpose is to create competitive advantage through value creation.

Business model canvas is a framework to map business activity which consists of the value network, functional architecture, financial modeling, and value proposition (Ballon, 2007). BMC's purpose is showing the integration map of business model. Value proposition as one of business model canvas values has a purpose as the positioning of the products or services to their customer (Zott et al., 2011). Since the purpose of the value proposition is positioning the value of the company in the customer's view, competitive advantage became an essential factor in determining the value proposition.

Porter, in 1985 already defined that competitive advantage is a serial of action in a company which related to a competitive strategy in order to create value that is important to customer
(Ensign, 2001). Porter describes the competitive advantage from an internal and external point of view. Reed and De Fillippi describe competitive advantage as competencies of the company (Uygur, 2015). While Hofer and Schendel describe competitive advantage as a unique position of company through customer experience (Ensign, 2001), it shows that competitive advantage is created within the company, and it is valued by consumers. Based on those facts, the correlation between value chain analysis and business model canvas lies in the creation of a value proposition to be offered to the customer through the company's competencies.

\section{METHODS}

The problem of this research is considered as a dynamic problem in which qualitative research methodology is chosen as a suitable method. Interview and consolidated study to understand the existing business model is conducted. Two main concepts are being used in this research, which is value chain analysis as proposed by (Pearce \& Robinson, 2008) and business model canvas as proposed by (Osterwalder \& Pigneur, 2010). 
Jurnal Bisnis dan Manajemen, Volume 20, No. 1, March 2019, p. 15-31

Value chain analysis is conducted in order to find the pros and cons of the internal company. Those results can be used to determine which value proposition that the company could use in its business model that can be implemented. Meanwhile, the business model canvas is the main concept of this research, which business model canvas can be easily understood by companies because it can describe the business model in a whole. Furthermore, in order to give a comprehensive solution, the financial aspect needs to be involved. Profitability ratios of various media companies are being used in order to compare the profitability index of the benchmarking company.

Several stages are being used in this research to find the objective. The first step is gathering information of revenue stream and value proposition from various Indonesian e-newspapers (Republika, Bisnis Indonesia, and Kompas) in order to find possible revenue stream and its relationship with the value proposition. Second, data collecting from PR and PT Infia Media Pratama (as a benchmarking company) related to value chain analysis and business model canvas. Third, mapping existing PR business model canvas and determine which the business model is already economically sustained or not. Fourth, mapping the business model canvas of PT IMP and measuring profitability ratio of the company. Fifth, measuring profitability ratio of a various Indonesian media company in Indonesia and consider it as a base point of media company profitability ratio. Sixth, comparing profitability ratio and determine which business model of PT IMP that already economically sustained or not. Last, mapping recommendation business model canvas.

There are some data that is needed in order to achieve the objective of this research. Primary data consists of all of value chain analysis and business model canvas variables. Primary data mining is conducted by an in-depth interview with an employee who has decision making capability. In PR, an interview is conducted with "Wakil Kepala Urusan" who has a responsibility to make e-newspaper running properly in PR. In PT IMP, an interview is conducted with the Chief Operational Officer, who has a responsibility to make sure business running properly. Informants are chosen based on their capability to determine policy. In-depth interview is conducted in semistructured form. Key information itself is regarding the value chain analysis and business model canvas which can be seen in table 2 . 
Jurnal Bisnis dan Manajemen, Volume 20, No. 1, March 2019, p. 15-31

Table 2. Key Information

\begin{tabular}{ll}
\hline Key Information & Key Informants \\
\hline Inbound Logistics & Pikiran Rakyat E-Newspaper \\
Operational & Pikiran Rakyat E-Newspaper \\
Outbound Logistics & Pikiran Rakyat E-Newspaper \\
Marketing \& Sales & Pikiran Rakyat E-Newspaper \\
Service & Pikiran Rakyat E-Newspaper \\
Firm Infrastructure & Pikiran Rakyat E-Newspaper \\
Technology & Pikiran Rakyat E-Newspaper \\
Development & \\
Human Resource & Pikiran Rakyat E-Newspaper \\
Management & \\
Procurement & Pikiran Rakyat E-Newspaper \\
Value Proposition & Pikiran Rakyat E-Newspaper \\
& PT Infia Media Pratama \\
Customer Segment & Pikiran Rakyat E-Newspaper \\
& PT Infia Media Pratama \\
Channels & Pikiran Rakyat E-Newspaper \\
& PT Infia Media Pratama \\
Customer Relationship & Pikiran Rakyat E-Newspaper \\
& PT Infia Media Pratama \\
Key Activities & Pikiran Rakyat E-Newspaper \\
& PT Infia Media Pratama \\
Key Resources & Pikiran Rakyat E-Newspaper \\
& PT Infia Media Pratama \\
Key Partnerships & Pikiran Rakyat E-Newspaper \\
& PT Infia Media Pratama \\
Cost Structures & Pikiran Rakyat E-Newspaper \\
& PT Infia Media Pratama \\
Revenue Streams & Pikiran Rakyat E-Newspaper \\
& PT Infia Media Pratama \\
\hline Source: processed data (2018)
\end{tabular}

Source: processed data (2018)

All of the data is collected from an informant who is credible in their field. This data can also be collected from any person or company in the related industry, which has expertise in the e- newspaper business model. Data from an existing customer is not needed since the behavior of enewspaper company can be seen on each enewspaper`s website with a google analytics tool. Secondary data mining is conducted by desk study. There are two kinds of data that is needed in this research, which are Indonesian e-newspaper condition and annual report of PT IMP and various Indonesian media companies. The report is needed in order to determine a company`s profitability ratio.

\section{RESULTS AND DISCUSSION}

\section{Indonesian E-Newspaper}

Some Indonesian newspaper companies already have e-newspaper. This research is benchmarking three big Indonesian newspaper companies, which are Republika, Kompas, and Bisnis Indonesia. All of those companies have different positioning. The primary purpose of comparing those companies is to find the possible revenue stream that already proven in other company beside PR. The result can be seen in table 3 .

Table 3. Revenue Stream and Value Proposition of Various Indonesian E-Newspaper

\begin{tabular}{llll}
\hline & Bisnis Indonesia & Kompas & Republika \\
\hline Revenue Stream & $\bullet$ E-Book & $\bullet$ E-Book & $\bullet$ E-paper \\
& $\bullet$ Web paper & $\bullet$ Ticket & $\bullet$ Photo \\
& $\bullet$ E-paper & $\bullet$ Photo & $\bullet$ Scrapbook \\
& - E-paper Apps & $\bullet$ E-paper & \\
& - Financial Data & & \\
& - Business Report & & \\
& $\bullet$ Experts Analyses & & E-newspaper which focusing \\
& Daily e-newspaper with & E-newspaper with \\
Value Proposition & credible business content & Independent, credible and & on the Muslim community in \\
& & balanced content & Indonesia \\
\hline
\end{tabular}

Source: Research result (2018) 
Jurnal Bisnis dan Manajemen, Volume 20, No. 1, March 2019, p. 15-31

Based on those results, it can be seen that possible revenue streams are related to their value proposition. Even though, Kompas has unrelated revenue stream which is selling ticket since Kompas is not focusing into community building. Based on research that is already conducted, Ticket's Product is not sustained at all. Since January-September 2018, Kompas is only selling one kind of event ticket which is held by Kompas itself. That is proof that the revenue stream is related to the value proposition of the company, especially the e-newspaper itself.

\section{Value Chain Analysis}

Value chain analysis is a method to analyze a company internally (Ensign, 2001). In this section is focusing on PR as a research object. This method aims to find the value proposition based on the strengths and weaknesses of the company.

\section{Primary Activity}

\section{Inbound Logistics}

The raw material of e-newspaper is news content. Content can be achieved from journalist and contributor either internal or external of the company.

\section{Operations}

E-newspaper operation in PR is still related with printed newspaper process. The process itself can be seen in figure 2 .

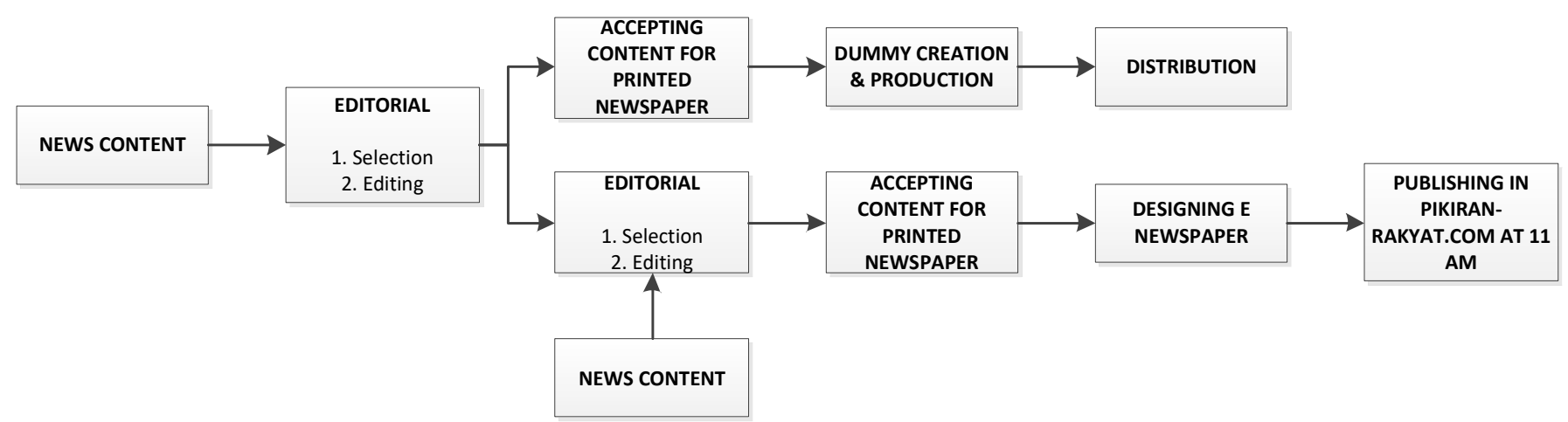

Figure 2. Pikiran Rakyat E-Newspaper Operational Process

Source: Research Result (2018)

\section{Outbound Logistics}

Outbound logistics process in e-newspaper is how the company distributed product into the customer's hand. PR e-newspaper has two channels to distribute their product through the website (pikiran-rakyat.com) and newsfeed (MyEdisi).

\section{Marketing and Sales}

Joining MyEdisi as a newsfeed application is one of marketing effort to promote PR e-newspaper. The other effort is maximizing SEO in order to increase pikiran-rakyat.com page rank in google. At this moment, PR is still not using above the line promotional media since e-newspaper is still in trial.

\section{Service}

There are two main factors in e-newspaper business for PR, which are journalist or contributor which propose content with the journalistic ethics that becomes a selling point for PR in order to sell their content. Second, the distribution channel for e- 
Jurnal Bisnis dan Manajemen, Volume 20, No. 1, March 2019, p. 15-31

newspaper is considered necessary since pikiranrakyat.com already has a high page rank in Google. Besides, collaboration with newsfeed also can be a benefit for them too. Based on the traffic's result, three main sections become highly attracted customer to read e-newspaper, which are Bandung Raya, Persib and West Java sections. Those sections always have the highest traffic among other section.

\section{Secondary Activity}

Firm Infrastructure

PR management already concerns about enewspaper in term of sustainability of their business. Potential customer also already shifted into millennial age, which they tend to use the digital platform in accessing news. Even so, PR only places four people in the newspaper division who were still considered to be lacking. Even though PR only put four persons in the enewspaper division, which consider a lack of personality. The condition happens because enewspaper is still in the trial, and no one considers as an expert. Furthermore, the e-newspaper division also has no clear job description for each of its employee. That is the reason why management still has not put more human resource.

\section{Technology Development}

PR is focusing on content provider company (news content). They did not put much effort into developing the technology itself. However, they have a server that is placed in Jakarta with outsourcing employee to maintain it.

\section{Human Resource Management}

Regarding human resource development, PR still prefers to use outsource employee to manage technology. Nevertheless, PR already put some organic employee in e-newspaper division to handle the content and operation process.

\section{Procurement}

Procurement in e-newspaper business is how the company is acquiring its content. PR gets its content either from an external or internal journalist or contributor. Even though every content needs to be edited in the editorial division in order to make sure the content is suitable and fulfill the journalistic ethics.

Based on value chain analysis, it can be concluded that PR e-newspaper has no strength point in technology at all besides they already have their own server. The main strength of PR e-newspaper is still in its content. Three main sections need extra supervision, which are Bandung Raya, Persib, and West Java section that has high traffic among the others.

\section{Business Model Canvas of PR E-Newspaper Value Proposition}

The value proposition is taken from the result of the value chain analysis. Based on value chain analysis, it can be concluded of PR's strength and weakness. PR's strength points are high traffic in Bandung Raya, Persib and West Java Content; newsfeed as collaborator partner; editing according to journalist ethic still has an important role, and medium to strong supporting activity especially in infrastructure. While PR's weaknesses itself are 
Jurnal Bisnis dan Manajemen, Volume 20, No. 1, March 2019, p. 15-31

low engagement in other general contents; IT support is not an organic employee; above the line promotion is considered weak. PR e-newspaper is focusing on their content as their value proposition. Based on the result of value chain analysis it can be concluded that the value proposition of PR enewspaper is e-newspaper that is distributed in the website and mobile application which focus in Bandung Raya, Persib and West Java content.

\section{Customer Segment}

At research time, PR could not show their google analytics regarding their customer because of technical error. Based on the interview, PR enewspaper is targeting millennial age which has an age range between 17-35 years old.

\section{Channels}

There are only two distribution channels that are used by PR in order to distribute e-newspaper to the customer which are pikiran-rakyat.com and MyEdisi.

\section{Customer Relationship}

There are two channels that can be used by the customer to communicate with the company or vice versa which are through the website and through PR social media.

\section{Key Activities}

Key activities for PR e-newspaper are receiving content, editing, designing for publishing enewspaper, publishing at 11 am daily, SEO and updating content daily, and maintaining MyEdisi application.

\section{Key Resources}

Key resources for e-newspaper are journalist or contributor, editorial team, website page rank, PR brand, server, and PR social media.

\section{Key Partnerships}

Important partners for PR e-newspaper are external journalist or contributor, external IT team, hosting and domain provider, Google, and developer of MyEdisi.

\section{Cost Structure}

Cost structures of PR e-newspaper are human resource, outsourced resource for server maintaining, hosting and domain, fee for external journalist or contributor, and social media admin (share with printed newspaper).

\section{Revenue Streams}

Right until this research is conducted, PR enewspaper still has not monetized its e-newspaper yet.

\section{Business Model Canvas Online Media Company in Indonesia (PT Infia Media Pratama)}

Benchmarking with another online media company also conducted in order to find insight from a similar company. E-newspaper company business is selling online content in order to gain benefit. This kind of business can be grouped into online media service companies even the content itself is different from each other. PT Infia Media Pratama (IMP) is chosen because PT IMP is an online media company with high revenue in Indonesia. Based on an interview with Chief Operation Officer of PT IMP, their business model canvas can be seen in the figure 3 . 
Jurnal Bisnis dan Manajemen, Volume 20, No. 1, March 2019, p. 15-31



Figure 3. Business Model Canvas of PT IMP

Source: Research Result (2018)

The differences between PR BMC and PT IMP BMC are PT IMP defines their customer as two types which are advertiser and audience. Based on customer definition, PT IMP also defines two value propositions for each segment. PT IMP also has intellectual property as their key resource which has a special character that already been patented. Even though, their intellectual property is not created revenue yet. PT IMP has three kinds of revenue stream, which are a digital advertisement, media placement, and commissioned sales.

Digital advertisement and media placement are actually a common form of media's revenue. The interesting part is, PT IMP has commissioned sales as their revenue stream. PT IMP only receives goods from the third party like a broker. Every piece that can be sold, PT IMP will gain some profit. Based on the interview, they called this model as online media commerce business model.

Those revenue streams already could give PT IMP profit that can make them sustain in this business. Profitability ratio in financial analysis is used in order to prove their profitability ratio.

Table 4. Profitability Ratio of PT Infia Media Pratama

\begin{tabular}{lrc}
\hline & $\begin{array}{c}\mathbf{2 0 1 6} \\
\text { (unaudited) }\end{array}$ & $\mathbf{2 0 1 7}$ \\
\hline Profit Margin & $21,90 \%$ & $13,91 \%$ \\
Return on Asset & $70,18 \%$ & $30,98 \%$ \\
Return on Equity & $76,29 \%$ & $33,35 \%$ \\
\hline
\end{tabular}

Source: (PT Infia Media Pratama, 2018)

Those results are shown the profitability ratio index of PT IMP. All of the ratios have a 
Jurnal Bisnis dan Manajemen, Volume 20, No. 1, March 2019, p. 15-31

positive value. All of the ratios above need to be industry. The profitability ratio of media industry compared with the profitability ratio of the media can be seen below.

Table 5. Profitability Ratio of some Media Companies in Indonesia

\begin{tabular}{lcccccccccccc}
\hline \multicolumn{1}{c}{ Item } & \multicolumn{2}{c}{ VIVA } & \multicolumn{2}{c}{ SCM } & \multicolumn{2}{c}{ Tempo } & \multicolumn{2}{c}{ Emtek } & & MNC & \multicolumn{2}{c}{$\begin{array}{c}\text { Average } \\
\text { Profitability }\end{array}$} \\
\hline & $\mathbf{2 0 1 6}$ & $\mathbf{2 0 1 7}$ & $\mathbf{2 0 1 6}$ & $\mathbf{2 0 1 7}$ & $\mathbf{2 0 1 7}$ & $\mathbf{2 0 1 6}$ & $\mathbf{2 0 1 7}$ & $\mathbf{2 0 1 6}$ & $\mathbf{2 0 1 7}$ & $\mathbf{2 0 1 6}$ & $\mathbf{2 0 1 7}$ & $\mathbf{2 0 1 6}$ \\
$\begin{array}{l}\text { Profit } \\
\text { Margin }\end{array}$ & $15,20 \%$ & $5,50 \%$ & $33,40 \%$ & $29,59 \%$ & $4,83 \%$ & $5,76 \%$ & $5,9 \%$ & $11,7 \%$ & $20,6 \%$ & $20,3 \%$ & $13,28 \%$ & $17,27 \%$ \\
$\begin{array}{l}\text { Return } \\
\text { on }\end{array}$ & & & & & & & & & & & & \\
$\begin{array}{l}\text { Asset } \\
\text { Return } \\
\text { on }\end{array}$ & $6 \%$ & $2 \%$ & $31,35 \%$ & $24,47 \%$ & $7,31 \%$ & $8,14 \%$ & $2,0 \%$ & $4,2 \%$ & $9,7 \%$ & $9,6 \%$ & $9,10 \%$ & $11,86 \%$ \\
Equity & $15,60 \%$ & $5,50 \%$ & $40,78 \%$ & $29,91 \%$ & $10,70 \%$ & $11,57 \%$ & $2,5 \%$ & $5,5 \%$ & $14,8 \%$ & $14,4 \%$ & $12,68 \%$ & $17,56 \%$ \\
\hline
\end{tabular}

Source: (Elang Mahkota Teknologi, 2018; Media Nusantara Citra, 2018; Surya Citra Media, 2018; Tempo Scan Pacific, 2018; Viva, 2018)

Based on comparing the profitability ratio, it shows that PT IMP already sustains based on profitability index (economic sustainability). It shows that PT IMP existing business model is proven to be an example in the meantime.

\section{Business Model Canvas Recommendations of PR E-Newspaper}

Purpose of recommendation business model (figure 4) is to ensure that PR e-newspaper can sustain in time when the printed paper is no longer can generate revenue. This recommendation is benchmarked through several possible revenue streams among other e-newspaper and a business model canvas from an online media company in Indonesia.

PR needs to define their customer into two types which are audience and advertiser since like other media, they also have two types of customer that need to be maintained. Both of customers can be possible revenue for PR e-newspaper. Actually, there are several possible revenue streams that PR can use in order to achieve economic sustainability. Furthermore, every possible revenue stream needs 
Jurnal Bisnis dan Manajemen, Volume 20, No. 1, March 2019, p. 15-31

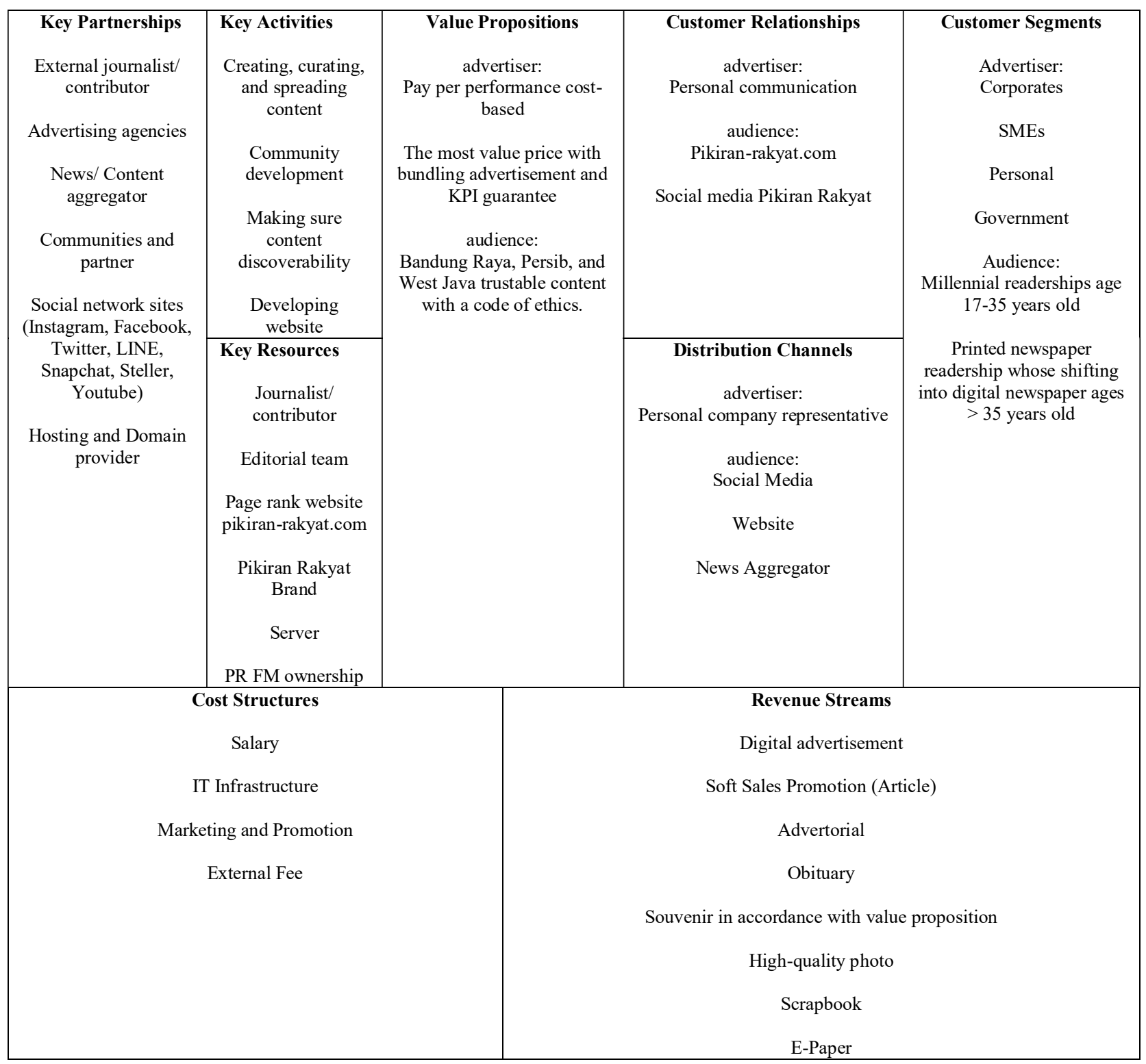

Figure 4. PR E-Newspaper Recommendation Business Model Canvas Source: Research Result (2018)

Michael Rappa in 2010 shows that there are nine types of e-commerce business model type. Furthermore, the business model is also adding value chain criteria as part of a business model (Abdollahi \& Leimstoll, 2011). Those results are based on this business model recommendation. 
Jurnal Bisnis dan Manajemen, Volume 20, No. 1, March 2019, p. 15-31

Table 6. Business Model Fragmentation by Criteria

\begin{tabular}{|c|c|c|c|c|c|c|c|c|c|c|}
\hline \multirow{3}{*}{ No } & \multirow{3}{*}{ Category } & \multicolumn{9}{|c|}{ Criteria } \\
\hline & & \multicolumn{3}{|c|}{ Traded Item } & \multicolumn{3}{|c|}{ Ownership } & \multicolumn{3}{|c|}{ Revenue } \\
\hline & & $\begin{array}{c}\text { Service/ } \\
\text { Immaterial }\end{array}$ & Goods & $\begin{array}{l}\text { Supplementary } \\
\text { Product }\end{array}$ & Production & Content & Intermediation & Direct & Commission & $\begin{array}{c}\text { Subscription } \\
\text { Fee }\end{array}$ \\
\hline 1 & $\begin{array}{l}\text { Brokerage } \\
\text { Model }\end{array}$ & $\mathrm{v}$ & & & $\mathrm{v}$ & & $\mathrm{v}$ & $\mathrm{v}$ & $\mathrm{v}$ & \\
\hline 2 & $\begin{array}{l}\text { Advertising } \\
\text { Model }\end{array}$ & $\mathrm{v}$ & $\mathrm{v}$ & & $\mathrm{v}$ & & $\mathrm{v}$ & $\mathrm{v}$ & $\mathrm{v}$ & $\mathrm{v}$ \\
\hline 3 & $\begin{array}{l}\text { Infomediary } \\
\text { Model }\end{array}$ & $\mathrm{v}$ & & $\mathrm{v}$ & $\mathrm{v}$ & & & $\mathrm{v}$ & & \\
\hline 4 & $\begin{array}{l}\text { Merchant } \\
\text { Model }\end{array}$ & $\mathrm{v}$ & $\mathrm{v}$ & $\mathrm{v}$ & $\mathrm{v}$ & & & $\mathrm{v}$ & & \\
\hline 5 & $\begin{array}{l}\text { Affiliate } \\
\text { Model }\end{array}$ & $\mathrm{v}$ & $\mathrm{v}$ & $\mathrm{v}$ & $\mathrm{v}$ & & & $\mathrm{v}$ & & \\
\hline 6 & $\begin{array}{l}\text { Manufacturer } \\
\text { Model }\end{array}$ & & $\mathrm{v}$ & & $\mathrm{v}$ & & & $\mathrm{v}$ & & \\
\hline 7 & $\begin{array}{l}\text { Community } \\
\text { Model }\end{array}$ & $\mathrm{v}$ & & $\mathrm{v}$ & $\mathrm{v}$ & $\mathrm{v}$ & & $\mathrm{v}$ & $\mathrm{v}$ & $\mathrm{v}$ \\
\hline 8 & $\begin{array}{l}\text { Subscription } \\
\text { Model }\end{array}$ & $\mathrm{v}$ & & & $\mathrm{v}$ & $\mathrm{v}$ & & & $\mathrm{v}$ & $\mathrm{v}$ \\
\hline 9 & $\begin{array}{l}\text { Utility } \\
\text { Model }\end{array}$ & $\mathrm{v}$ & & & & $\mathrm{v}$ & & & & $\mathrm{v}$ \\
\hline
\end{tabular}

Source: (Abdollahi \& Leimstoll, 2011)

Based on the table above, e-newspaper companies in Indonesia mostly use a subscription model as their business model since the subscription fee is their main revenue stream. Besides, the advertising model also can be chosen for e-newspaper that focusing on advertising only. Even though, the recommendation for PR e-newspaper is needed to focus on community model which this model is focusing on content ownership. Even there are plenty online media who already provide Bandung Raya, Persib and West Java contents, there is still a little who has the capability to present it with reliable content and refer to journalistic ethics. When their content discoverability is already high in online media, PR needs to switch to an advertising model in order to generate revenue and achieving economic sustainability.

\section{CONCLUSION}

This study manages to find several things for the newspaper industry to survive in this era. Enewspaper is no longer a choice and newspaper companies need to switch into it. E-newspaper is considered as online media which newspaper company should compete on a new level not only newspaper companies but also with online media companies. First, e-newspaper should determine their customer into two which are audience and advertiser. Second, e-newspaper should define its revenue stream associated with its value proposition. Third, determine other business model canvas variable related to customer segment, value proposition, and revenue stream. Fourth, implementing a business model that is not only fixated on one business model fragment. Fifth, checking financial ratio and comparing it with the 
Jurnal Bisnis dan Manajemen, Volume 20, No. 1, March 2019, p. 15-31

industry's score and determining whether the business model is already suitable or not.

\section{REFERENCES}

Abdollahi, G., \& Leimstoll, U. (2011). A Classification for Business Model Types in E-commerce. AMCIS 2011 Proceedings All Submissions, 88.

Abecassis-Moedas, C. (2006). Integrating design and retail in the clothing value chain: An empirical study of the organisation of design. International Journal of Operations and Production Management, 26(4), 412-428. https://doi.org/10.1108/01443570610650567

Ankli, R. E. (2014). Michael Porter's Competitive Advantage and Business Michael Porter' s Competitive Advantage and Business History, (March).

Ballon, P. (2007). Business modelling revisited: The configuration of control and value. Info, 9(5), 6-19. https://doi.org/10.1108/14636690710816417

Chivaka, R. (2005). Cost management along the supply chain-Methodological implications. Research Methodologies in Supply Chain Management: In Collaboration with Magnus Westhaus, 1954(March), 299-314. https://doi.org/10.1007/3-7908-1636-1_20

Coes, B. (2014). CRITICALLY ASSESSING THE STRENGTHS AND LIMITATIONS OF THE Master thesis Business Administration. University of Twente, 1 to 99. Retrieved from https://www.google.co.uk/search?client=firef ox$\mathrm{b} \& \mathrm{q}=$ essay.uwente.nl $\% 2 \mathrm{~F} 64749 \% 2 \mathrm{Fl} \% 2 \mathrm{FCo}$ es_MA_MB.PDF\&oq=essay.uwente.nl\%2F6 $4749 \% 2 \mathrm{Fl} \% 2 \mathrm{FCoes}$ _MA_MB.PDF\&gs_l=ps $\mathrm{y}-$ ab.12..16773.34806.0.37240.7.7.0.0.0.0.139 2.2210.3j1j4-1j7-1.6.0...0...1.1.64.psyab..1.0.0.hltgvWBq

Danskin, P., Englis, B., \& Solomon, M. R. (2005). Knowledge management as competitive advantage: Lessons from the textile and apparel value chain Knowledge management as competitive advantage : lessons from the textile and a ... Paula Danskin; Basil G Englis ; Michael R Solomon; Marla Goldsmith ; Jenn, (June 2014). https://doi.org/10.1108/13673270510590245

Elang Mahkota Teknologi. (2018). Laporan

Tahunan 2017 Maintaining both Largest in

FTA and Content. Retrieved from http://www.emtek.co.id/files/uploads/report/f ile_en/2018/May/25/5b07f9e3c1772/annualreport-2017.pdf

Ensign, P. C. (2001). Value Chain Analysis and Competitive Advantage: Assessing Strategic Linkages and Interrelationships. Journal of General Management, 27(1), 18-42.

Retrieved from https://pdfs.semanticscholar.org/d0cd/9f9a36 d579afe611f12db0385788f28aadf5.pdf

Flavian, C., Gurrea, R., \& Orús, C. (2009). Web design: a key factor for the website success. Journal of Systems and Information Technology, 11(2), 168-184. https://doi.org/https://doi.org/10.1108/13287 260910955129

Hendrix, T., Hidayat, A., \& Hidayat, M. (2018). Implementing Business Model Canvas for Cibinong Science and Technology Park Penerapan Proses Bisnis Model Canvas pada Cibinong Science and Technology Park, XIX(1), 47-58.

Lubis, M. (2017). Media Cetak Mampu Mempertahankan Posisinya. Retrieved from https://www.nielsen.com/id/en/pressroom/2017/MEDIA-CETAK-MAMPUMEMPERTAHANKANPOSISINYA.print.html

Media Nusantara Citra. (2018). Laporan Tahunan 2017 Maintaining both Largest in FTA and Content. Retrieved from https://www.mnc.co.id/ir/annual_reports/en\# content

Meijer, J. H. and M. (2006). Guidelines for value chain analysis Guidelines for value chain analysis Jon Hellin and Madelon Meijer, (July).

Networks, V., \& Wilson, D. T. (2001). Kothandaraman The future of competitionValue-creating networks.pdf, 389(814), 379389. https://doi.org/10.1016/S00198501(00)00152-8

Nielsen. (2015). Newspaper and Magazine Readership.

Osterwalder, A., \& Pigneur, Y. (2010). Business Model Generation: A Handbook for Visionaries, Game Changers, and 
Jurnal Bisnis dan Manajemen, Volume 20, No. 1, March 2019, p. 15-31

Challengers. John Wiley \& Sons.

Osterwalder, A., Pigneur, Y., \& Tucci, C. L. (2005). Clarifying Business Models: Origins, Present, and Future of the Concept.

Communications of the Association for Information Systems. Communications of the Association for Information Systems, 16(16), 751-775.

https://doi.org/10.17705/1CAIS.01601

Ottosen, R., \& Krumsvik, A. H. (2012). Digital Challenges on the Norwegian Media Scene. Nordicom Review, 33(2), 43-55. Retrieved from https://core.ac.uk/download/pdf/35073982.pd $\mathrm{f}$

Pearce, J. A., \& Robinson, R. B. (2008). Manajemen Strategis, Formulasi, Implementasi dan Pengendalian. Jakarta: Salemba Empat.

PT Infia Media Pratama. (2018). Financial Statement and Independence Auditor's Report of PT Infia Media Pratama 2016 (unaudited) and 2017 (audited).

Republika. (2011). SPS:Pembaca Koran Tinggal 15 Persen. Retrieved from https://www.republika.co.id/berita/nasional/u mum/11/10/21/1tf33z-spspembaca-korantinggal-15-persen

Sheftiawan, D. (2017). Pikiran Rakyat Peringkat Ke-2 Nasional Media Berbahasa Indonesia Terbaik. Pikiran Rakyat. Retrieved from https://www.pikiranrakyat.com/nasional/2017/10/30/pikiranrakyat-peringkat-ke-2-nasional-mediaberbahasa-indonesia-terbaik-412601 Soltani, S. (2012). STRATEGIC MARKETING PLAN IN PRODUCT LIFE CYCLE (More Profitability in Stages of Product Life Cycling) Case; PLC of HP and ACER laptop. VAASAN AMMATTIKORKEAKOULU UNIVERSITY OF APPLIED SCIENCES. Retrieved from https://www.theseus.fi/bitstream/handle/1002 4/47037/plc tez.pdf? sequence $=1$

Sun, Y.-S., \& Guo, S. (2004). Media Use, Social Comparison, Cognitive Dissonance and Peer Pressure as Antecedents of Fashion Involvement. Media Use, Social Comparison, Cognitive Dissonance and Peer Pressure as Antecedents of Fashion Involvement. Retrieved from
https://web.uri.edu/iaics/files/10Yan-ShuSun-Steve-Guo.pdf

Surya Citra Media. (2018). Laporan Tahunan 2017 Empowering Creativity to Capture Opportunity. Retrieved from http://scm.co.id/annual-reports

Tempo Scan Pacific. (2018). Laporan Tahunan 2017. Retrieved from http://www.thetempogroup.net/images/TSP AR_2017.pdf

Uygur, U. (2015). Determinants of causal ambiguity and difficulty of knowledge transfer within the firm Organization : Determinants of causal ambiguity and difficulty of knowledge transfer within the firm, (May).

https://doi.org/10.1017/jmo.2014.12

Viva. (2018). Annual Report 2017 Interactive for Growth. Retrieved from https://res.cloudinary.com/pt-visi-media-asiatbk/image/upload/enstaticviva/AnnualReport-VIVA-2017.pdf

Zott, C., Amit, R., \& Massa, L. (2011). The business model: Recent developments and future research. Journal of Management, 37(4), 1019-1042. https://doi.org/10.1177/0149206311406265 